\title{
PERAN KEPEMIMPINAN KEPALA SEKOLAH DALAM MENINGKATKAN DISIPLIN KERJA GURU DAN PEGAWAI DI SMP PGRI 03 KENCONG JEMBER
}

\author{
Nuriyah Fikri Wahyuni ${ }^{1}$, Siti Fatikhah Nur Aini ${ }^{2}$, Umul Ulfa Mufida ${ }^{3}$, Abdul Muhith ${ }^{4}$ \\ ${ }^{1}$ IAIN Jember, Jl. Mataram No.1 Mangli Jember, Jawa Timur Indonesia \\ e-mail: nuriyahfikriwahyuni@gmail.com \\ ${ }^{2}$ IAIN Jember, Jl. Mataram No.1 Mangli Jember, Jawa Timur Indonesia \\ e-mail: tika12970@gmail.com \\ ${ }^{3}$ IAIN Jember, Jl. Mataram No.1 Mangli Jember, Jawa Timur Indonesia \\ e-mail: ulfamufida01@gmail.com \\ ${ }^{3}$ IAIN Jember, Jl. Mataram No.1 Mangli Jember, Jawa Timur Indonesia \\ e-mail: abdmuhith1972@gmail.com
}

\begin{abstract}
This study aims to identify and describe the role of principal leadership in improving the work discipline of teachers and employees and to find out what obstacles are the obstacles to the role of principal leadership in improving the work discipline of teachers and employees at SMP PGRI 03 Kencong, Jember Regency. Is a type of qualitative descriptive research and uses purposive sampling technique. There are five roles of the Principal and two obstacles faced by the Principal in improving the work discipline of teachers and employees. The results showed that the principal of SMP PGRI 03 Kencong, Jember Regency carried out the role of a leader by planning and deliberating; as a manager by creating collaboration between teachers and employees; as an educator by preparing a learning program plan; as an administrator by managing facilities and infrastructure as well as financial administration; motivator by providing motivation with a conducive school environment. The obstacles faced by the principal in improving the work discipline of teachers and employees are teachers and employees who are less disciplined in carrying out their duties so that it is also difficult to improve their work discipline, as well as obstacles in inadequate school facilities and infrastructure.
\end{abstract}

Keywords: leadership, principals, work discipline, teachers, employees

\section{ABSTRAK}

Penelitian ini bertujuan untuk mengetahui dan mendeskripsikan peran kepemimpinan kepala sekolah dalam meningkatkan disiplin kerja guru dan pegawai dan untuk mengetahui kendala apa saja yang menjadi penghambat peran kepemimpinan kepala sekolah dalam meningkatkan disiplin kerja guru dan pegawai di SMP PGRI 03 Kencong Kabupaten Jember. Penelitian ini merupakan jenis penelitian deskriptif kualitatif dan menggunakan teknik Purposive Sampling. Terdapat lima peran Kepala Sekolah dan dua kendala yang dihadapi oleh Kepala Sekolah dalam meningkatkan 
disiplin kerja guru dan pegawai. Dari hasil penelitian menunjukkan bahwa kepala sekolah SMP PGRI 03 Kencong Kabupaten Jember melaksanakan peran sebagai pemimpin dengan membuat perencanaan dan bermusyawarah; sebagai manajer dengan menciptakan kerjasama antara guru dan pegawai; sebagai pendidik dengan menyusun rencana program pembelajaran;sebagai administrator dengan mengelola sarana dan prasarana serta administrasi keuangan; motivator dengan memberikan motivasi dengan lingkungan sekolah yang kondusif. Kendala yang dihadapi kepala sekolah dalam meningkatkan disiplin kerja guru dan pegawai yaitu guru dan pegawai yang kurang disiplin dalam melaksanakan tugas sehingga kesulitan pula dalam meningkatkan disiplin kerjanya, serta kendala dalam sarana dan prasarana sekolah yang belum memadai.

Kata Kunci: kepemimpinan, kepala sekolah, disiplin kerja, guru, pegawai

\section{PENDAHULUAN}

Sebagaimana disadari bahwa sekolah adalah salah satu jenis organisasi yang sering disebut organisasi pendidikan formal. Salah satu unsur organisasinya yang paling penting adalah manusianya, personil interen organisasi sekolah terdiri dari kepala sekolah, guru - guru, siswa / siswi dan pegawai tata usaha sekolah. Kegiatan pokok yang mereka kerjakan ialah kegiatan belajar mengajar. Hal ini sesuai dengan tujuan Negara Indonesia yang tercermin dalam alenia keempat pembukaan Undang - Undang Dasar Tahun 1945 yang menyatakan "kemudian dari pada itu, untuk membentuk suatu pemerintahan Negara Indonesia yang melindungi segenap bangsa Indonesia dan seluruh tumpah darah Indonesia dan untuk memajukan kesejahteraan umum, mencerdaskan kehidupan bangsa dan ikut melaksanakan ketertiban dunia". Pemerintah mengusahakan dan menyelenggarakan satu sistem pengajaran nasional yang diatur dengan UUD pasal 31 ayat 3, pemerintah juga mengeluarkan Undang - Undang Nomor 20 tahun 2003 tentang sistem pendidikan nasional.

Indonesia yang menyelenggarakan pendidikan tentu memiliki filosofi dan ideologi tersendiri dalam pengembangan dunia pendidikan. Pemerintah melalui Departemen Pendidikan Nasional (DEPDIKNAS) sebagai wakil dari pemerintah, bertanggung jawab lebih terhadap pendidikan di Indonesia, terus berupaya menjalankan dan mengembangkan serta meningkatkan kualitas / mutu Pendidikan Nasional dengan interpretasinya sendiri. Agar proses pendidikan sekolah dengan baik, tentunya diperlukan tenaga - tenaga pengajar yang berkualitas, memiliki loyalitas serta disiplin yang tinggi. Disiplin yang tinggi akan sangat membantu dalam upaya pencapaian tujuan, sedangkan untuk mewujudkan suatu kondisi disiplin maka diperlukan adanya seorang pemimpin yang benar - benar cakap dalam menjalankan tugas dan tanggung jawabnya dalam menjalankan manejemen sekolah, yaitu proses kerja dengan dan melalui ( mendayagunakan ) orang lain untuk mencapai tujuan organisasi secara efesien ( depdiknas, 2001 : $14)$. 
Namun demikian, untuk menciptakan kondisi tersebut nampaknya masih memerlukan proses agar kepala sekolah dapat meningkatkan disiplin kerja pegawai dan guru. Hal tersebut dapat dilihat dari hasil observasi sementara di SMP PGRI 03 Kencong Jember, terdapat indikasi yang mengarah pada rendahnya disiplin kerja pegawai dan guru antara lain : 1). pegawai dan guru yang tidak masuk kerja tanpa keterangan yang jelas; 2). kerapian pada penggunaan seragam yang telah di tentukan sekolah; 3). pada waktu proses belajar mengajar ada guru yang belum berada di tempat

Masih adanya guru dan pegawai yang terlambat datang ke sekolah dan pulang sebelum jam yang telah di tentukan sekolah. Berdasarkan uraian diatas maka disiplin kerja dari pada guru dan pegawai harus ditingkatkan menjadi yang lebih baik lagi. Menyadari pentingnya disiplin kerja dalam rangka mencapai visi dan misi di sekolah, maka diperlukan peran kepemimpinan yang baik dalam meningkatkan disiplin kerja guru dan pegawai.dengan uraian tersebut maka penulis tertarik untuk memilih judul : “Peran Kepemimpinan Kepala Sekolah Dalam Meningkatkan Disiplin Kerja Guru Dan Pegawai Di SMP PGRI 03 Kencong-Jember".

\section{Kepemimpinan}

Kepemimpinan merupakan proses mempengaruhi orang lain untuk mengambil langkah langkah atau tindakan menuju suatu sasaran bersama. Karena itu kepemimpinan adalah kegiatan mempengaruhi orang lain agar mau bekerja untuk mencapai tujuan yang telah ditentukan.

C.N.Cooley dalam (Inu 2003 : 132) menyatakan pemimpin itu selalu merupakan titik pusat dari suatu kecenderungan dan pada kesempatan lain, semua gerakan sosial kalau diamati secara cermat akan semangat dapat menyelesaikan pekerjaannya masing - masing dengan hasil yang diharapkan.

Selanjutnya kepemimpinan menurut Rivai (2004 : 2) kepemimpinan secara luas meliputi proses mempengaruhi proses mempengaruhi dalam menentukan tujuan organisasi, memotivasi prilaku pengikut untuk mencapai tujuan, mempengaruhi untuk memperbaiki kelompok atau budayanya. Menurut Rivai ( 2002 : 149 - 150 ) Peran kepemimpinan dapat pula di bagi menjadi : 1). Pemimpin masa depan harus flesibel dan mempunyai pengalaman yang luas. 2). Menganggap tanggung jawab " seremonial " atau spiritual " sebagai kepala organisasi menjadi suatu fungsi yang diperlukan, bukan suatu hal yang remeh yang harus dialami atau didelegasikan kepada orang lain. 3). Peraturan tidak lagi di buat secara efektif terpusat di puncak organisasi.

Purwanto (2008 : 48 - 52) mengatakan gaya kepemimpinan di bagi menjadi 3 ( tiga ) yaitu sebagai berikut :1). Kepemimpian yang otokratik. Dalam kepemimpinan yang otokratik, pemimpin bertindak sebagai ditator terhadap anggota - anggota kelompoknya. Baginya, memimpin adalah menggerakkan dan memaksa kelompok. Kekuasaan pemimpin yang otokratik hanya dibatasi oleh undang - undang penafsirannya sebagai pemimpin tidak lain adalah menunjukkan dan memberi perintah, kewajiban bawahan atau anggota - anggotanya hanyalah mengikuti dan menjalankan tidak boleh membantah ataupun memberikan saran; 2). Kepemimpinan yang laissez faire. Dalam 
gaya kepemimpinan ini sebenarnya pemimpin tidak memberikan pimpinan. Gaya ini diartikan sebagai membiarkan orang - orang berbuat sekehendaknya. Pemimpin yang termasuk gaya ini sama sekali tidak memberikan control dan koreksi terhadap pekerjaan anggota - anggotanya. Pembagian tugas dan kerja sama diserahkan kepada anggota - anggota kelompoknya., tanpa petunjuk atau saran - saran dari pimpinan. Kekuasaan dan tanggung jawab simpang siur berserakan diantara anggota - anggota kelompok, tidak merata; 3). Kepemimpinan Yang Demokratis Pemimpin yang memiliki gaya demokratis menafsirkan kepemimpinannya bukan sebagai diktator, melainkan sebagai pemimpin di tengah - tengah anggota kelompoknya. Hubungan dengan anggota - anggota kelompok bukan sebagai majikan terhadap buruhnya, melainkan sebagai saudara tua di antara teman - teman - teman sekerjanya, atau sebagai kakak terhadap saudara - saudaranya. Pemimpin yang demokratis selalu berusaha menstimulasi anggota - anggotanya agar bekerja secara kooperatif untuk mencapai tujuan bersama. Dalam tindakan dan usaha - usahanya, ia selalu berpangkal pada kepentingan dan kebutuhan kelompoknya dan mempertimbangkan kesanggupan serta kemampuan kelompoknya; 4). Peran Kepemimpinan. Menurut Rivai (2002 : 148) peran dapat diartikan sebagai perilaku yang diatur dan diharapkan dari seseorang dalam posisi tertentu. Pemimpin di dalam organisasi mempunyai peranan, setiap pekerjaan membawa serta harapan bagaimana penanggung peran berperilaku.

Peran kepemimpinan dalam tim menurut kepemimpinan yang berorientasi pada memelihara kelompok adalah sebagai berikut : a). penjagaan gawang (gatekeeping); b). mengharmoniskan ( harmonizing ); c). mendukung ( supporting ); menerangkan standar ( standard setting); d). menganalisis proses ( analyzing process )

\section{Kepala Sekolah}

Kepala sekolah merupakan salah satu komponen pendidikan yang paling berperan penting dalam meningkatkan kualitas pendidikan. Kepala sekolah adalah seorang tenaga fungsional guru, yang diberi tugas untuk memimpin suatu sekolah dimana diselenggarakannya proses belajar mengajar, atau tempat dimana terjadi interaksi guru dalam memberi pelajaran dan murid menerima pelajaran (Wahjosumijo 2002).

Perspektif kedepan mengisyaratkan bahwa kepala sekolah juga harus mampu berperan sebagai figur dan mediator. Beberapa peran kepala sekolah dalam paradigma baru manajemen pendidikan yaitu sebagai berikut (Mulyasa 2007) :1) Kepala sekolah sebagai pemimpin; 2). kepala sekolah sebagai manajer; 3). kepala sekolah sebagai pendidik; 4). kepala sekolah sebagai administrator; 5). Kepala sekolah sebagai motivator

\section{Disiplin Kerja}

Menurut peraturan pemerintah No.53 Tahun 2010 tentang peraturan disiplin pegawai negeri sipil. Mendefinisikan disiplin kerja adalah sikap atau perilaku kesanggupan pegawai negeri sipil untuk mentaati kewajiban dan menghindari larangan yang telah ditentukan dalam peraturan 
perundang - undangan dan/ atau peraturan kedinasan yang apabila tidak ditaati atau dilanggar akan dijatuhkan hukuman disiplin. Irmin (2004 : 21) memberikan pengertian tentang disiplin, yaitu merupakan sikap taat dan tertip sebagai hasil pengembangan dan latihan pengendalian pikiran dan pengendalian watak.

Menurut Hasibuan (2005 : 193), disiplin adalah kesadaran dan kesediaan seseorang mentaati peraturan perusahaan dan norma - norma sosial yang berlaku. Sastrohadiwiryo (2003 : 291) mengatakan disiplin kerja adalah sebagai sikap menghormati, menghargai, patuh dan taat terhadap peraturan - peraturan yang berlaku, baik secara tertulis maupun tidak tertulis serta sanggup menjalankan dan tidak mengelak untuk menerima sanksi - sanksi nya apa bila seseorang melanggar tugas dan wewenang yang diberikan kepadanya. Sedangkan Rivai (2003 : 444) mengatakan disiplin kerja adalah suatu alat yang digunakan para manajer untuk berkomunikasi dengan karyawan agar mereka bersedian untuk meningkatkan kesadaran dan kesediaan seseorang mentaati semua peraturan perusahan dan norma - norma yang berlaku.

Jadi, Kepemimpinan Kepala Sekolah dalam meningkatkan disiplin kerja guru dan pegawai adalah suatu cara yang digunakan kepala sekolah dalam mempengaruhi, menuntun dan membimbing guru dan pegawai untuk bersama - sama melakukan pekerjaan yang telah di tentukan besama - sama sehingga dapat menanamkan jiwa disiplin kerja guru dan pegawai untuk mencapai tujuan sekolah yang telah ditentukan bersama - sama.

\section{METODE}

Jenis penelitian yang digunakan dalam penelitian ini adalah jenis penelitian deskriptif kualitatif. Lokasi dalam penelitian yang dilakukan adalah SMP PGRI 03 Kencong-Jember. Sumber data yang penulis ambil adalah data primer dan data sekunder. Data sekunder meliputi dokumen, arsip, laporan, evaluasi buku ilmiah.

Dalam penelitian ini penelitian narasumber dilakukan melalui Teknik purposive sampling. Orang yang menjadi key informan dalam penggunaan teknik ini adalah Kepala Sekolah SMP PGRI 03 Kencong-Jember dan yang menjadi informannya adalah guru dan pegawai SMP PGRI 03 Kencong-Jember.

Teknik pengumpulan data menggunakan teknik penelitian kepustakaan (Library research) dan penelitian lapangan (Field work research), penelitian lapangan sendiri terdiri dari observasi, wawancara, studi dokumen dan dokumentasi.

Teknik analisis data yang digunakan dalam penelitian ini adalah analisis data model interaktif yang dikemukakan oleh Miles dan Huberman, yakni pengumpulan data, penyederhanaan data (data reduction), penyajian data (data display), dan penarikan kesimpulan (conclution drawing)

\section{HASIL DAN PEMBAHASAN}

\section{Peranan Kepemimpinan Kepala Sekolah}




\section{Kepala sekolah sebagai pemimpin}

Kepala sekolah adalah pimpinan tertinggi di sekolah yang dipimpinnya. Pola kepemimpinannya akan sangat berpengaruh bahkan akan sangat menentukan terhadap kemajuan sekolah. Kepemimpinan kepala sekolah adalah cara atau usaha kepala sekolah dalam mempengaruhi, mendorong, membimbing, mengarahkan, dan menggerakkan guru, staf, siswa, orang tua siswa dan pihak lain yang terkait untuk bekerja atau berperan serta dalam usaha mencapai tujuan yang telah ditetapkan.

Kepala sekolah sebagai seorang pemimpin tentunya akan memiliki kemampuan atau kecakapan-kecakapan yang mendukung kemampuannya sebagai seorang pemimpin di sekolah seperti kemampuan berkomunikasi yang baik, memiliki kemampuan teknis dalam bidangnya, memiliki kemampuan analitis yang tajam, bersikap tegas dan berani mengambil keputusan, etos kerjanya tinggi dan memiliki visi yang jelas. Kedudukan kepala sekolah adalah pemimpin tertinggi dan harus membawahi, mengayomi semua sumberdaya manusia di sekolah tersebut.

Dalam peran ini, kepala sekolah adalah penanggung jawab terhadap pelaksanaan keseluruhan proses pendidikan di sekolah yang dilakukan oleh seluruh unsur warga sekolah. Sebagai seorang pemimpin, wajar jika kepala sekolah dituntut untuk mengupayakan pelaksanaan proses pendidikan secara efektif dan efisien.

Dalam pelaksanaan tugasnya, seorang kepala sekolah memiliki beberapa fungsi atau peran penting. Selain sebagai pemimpin, peranan kepala sekolah dalam hubungannya dengan pencapaian tujuan lembaga adalah sebagai manajer, sebagai administrator, sebagai pendidik, kepala sekolah juga harus mampu menggerakan seluruh warga sekolah baik guru, siswa, orang tua siswa, masyarakat dan sarana pendidikan untuk mencapai tujuan pendidikan. Kepala sekolah dalam menjalankan tugasnya perlu memiliki prinsip - prinsip kepemimpinan.

Prinsip kepemimpinan kepala sekolah tersebut antara lain konstruktif, kreatif, partisipatif, kooperatif, delegatif, integratif, rasional dan objektif. Keberadaan kepala sekolah dalam setiap jenjang pendidikan sangatlah penting. Dengan terpusatnya kewenangan sekolah ditangan kepala sekolah, maka sekolah menjadi fitur sentral sebagai pemimpin tertinggi dan menjadi penentu keberhasilan sekolah dalam mencapai tujuan yang diharapkan. Keberadaan kepala sekolah kaitannya dengan keberhasilan mencapai tujuan pendidikan, sangat ditentukan oleh pengelolaan sekolah.

Pengelolaan sekolah yang berhasil sangat ditentukan oleh kepemimpinan kepala sekolah. Keberadaan kepala sekolah tersebut sangat terkait dengan kemampuan dalam mengelola sekolah. Tugas dan tanggung jawab merupakan sesuatu hal yang harus dilaksanakan oleh seseorang dalam memangku suatu jabatan. Demikian pula dengan tugas dan tanggung jawab kepala sekolah. Kepala sekolah adalah pemimpin pendidikan yang memiliki peranan sangat besar dalam mengembangkan mutu pendidikan di sekolah. Berkembangnya semangat kerja, kerjasama yang harmonis, minat 
terhadap perkembangan pendidikan, suasana kerja yang menyenangkan dan perkembangan mutu profesional di antara para guru, banyak ditentukan oleh kualitas kepemimpinan kepala sekolah.

Dengan demikian kepala sekolah adalah salah satu kunci keberhasilan sekolah dalam mencapai tujuannya. Dari pernyataan diatas jelas bahwa kepala sekolah mampu melaksanakan perannya sebagai pemimpin di SMP PGRI 03 Kencong-Jember terbukti kepala sekolah telah mampu merumuskan dan menentukan tujuan sekolah yang akan di capai sekolah dan memutuskan perancanaan tersebut dengan cara rapat dan menerima saran atau masukan dari guru dan pegawai yang ada di sekolah.

\section{Kepala Sekolah Sebagai Manajer}

Peran kepala sekolah sebagai manajer dalam mempenggaruhi guru untuk mewujudkan tujuan yang diinginkan kepala sekolah harus mampu menciptakan kerjasama atau kooperatif yang dimaksudkan bahwa dalam peningkatan kinerja guru di sekolah, kepala sekolah harus mementingkan kerjasama dengan guru dan pihak lain yang terkait dalam melaksanakan setiap kegiatan. Sebagai manajer kepala sekolah harus mau dan mampu mendayagunakan seluruh sumber daya sekolah dalam neingkatkan visi, misi dan mencapai tujuan. Kepala sekolah mewajibkan setiap guru mata pelajaran harus melaksanakan proses pembelajaran yang mengacu pada standar kelulusan dan melaksanakan musyawarah guru mata pelajaran yang ada di sekolah.

Kepala sekolah sebagai manajer memiliki peran yang kuat dalam mengkoordinasikan, menggerakkan dan menyelerasikan semua sumber daya pendidikan yang tersedia di sekolah. Kepemimpinan kepala sekolah di SMP PGRI 03 Kencong-Jember merupakan salah satu faktor yang dapat mendorong sekolah untuk dapat mewujudkan visi, misi dan tujuan sekolah melalui program - program yang dilaksanakan secara terancana dan bertahap. Oleh karena itu kepala sekolah dituntuk mempunyai kemampuan menajemen dan kepemimpinan yang memadai agar mampu mengambil inisiatif dan prakarsa untuk meningkatkan mutu sekolah.

Kepala sekolah sebagai manajer harus mampu merencanakan setiap tindakan yang akan diterapkan disekolah, sebaiknya setiap kegiatan yang akan dilaksanakan tidak boleh terlepas dari proses perencanaan, sebab semua kegiatan sekolah bisa sukses karena pada umumnya direncanakan dengan matang. Kepala sekolah yang di bantu wali kelas dan guru - guru selalu mengadakan musyawarah bersama untuk memperbaiki kelemahan - kelemahan yang mungkin terjadi di sekolah dalam proses belajar mengajar.

Kepala sekolah setiap selesai upacara bendera memberikan semangat kepada guru dan pegawai supaya guru dan pegawai dapat melaksanakan tugas serta pekerjaannya dengan rasa tanggung jawab dan dapat mencapai tujuan sekolah yang telah ditetapkan bersama, dari sini terbukti kepala sekolah telah melakukan untuk dapat membangkitkan semangat guru dan pegawai agar dapat melaksanakan pekerjaan dan tugasnya agar bekerja dengan baik.

\section{Kepala Sekolah Sebagai Pendidik}


Pendidik adalah orang yang mendidik, sedangkan mendidik diartikan memberikan latihan (ajaran, pimpinan) mengenai akhlak dan kecerdasan pikiran sehingga pendidikan dapat diartikan proses pengubahan sikap dan tata laku seseorang atau kelompok orang dalam usaha mendewasakan manusia melalui upaya pengajaran dan latihan.

Sebagai seorang pendidik kepala sekolah harus mampu menanamkan, memajukan dan meningkatkan empat macam nilai, yaitu: 1). Mental, hal-hal yang berkaitan dengan sikap batin dan watak manusia; 2). Moral, hal-hal yang berkaitan dengan ajaran baik buruk mengenai perbuatan, sikap dan kewajiban atau moral; 3). Fisik, hal-hal yang berkaitan dengan kondisi jasmani atau badan, kesehatan dan penampilan manusia secara lahiriah; 4). Artistik, hal-hal yang berkaitan kepekaan manusia terhadap seni dan keindahan.

Maka hal yang perlu diperhatikan oleh seorang kepala sekolah sebagai pendidik mencakup dua hal pokok yaitu sasaran atau kepada siapa perilaku sebagai pendidik itu diarahkan dan bagaimana peranan sebagai pendidik itu dilaksanakan. Oleh karena itu ada tiga yang menjadi sasaran utamanya yaitu para guru atau tenaga fungsional yang lain, tenaga administratif ( staf atau pegawai ) dan para siswa atau peserta didik. Disamping ketiga sasaran utama pelaksanaan peranan kepala sekolah sebagai pendidik, terdapat pula kelompok sasaran lain yang tidak kalah pentingnya yaitu organisasi orang tua siswa, organisasi siswa, dan organisasi para guru.

Keberadaan organisasi orang tua siswa lebih banyak diperlukan untuk membantu dan mengatasi keperluan berbagai sumber daya dalam membina kehidupan kepala sekolah, baik berupa dana, sarana, jasa maupun pemikiranpemikiran juga membantu pelaksanaan pembinaan kesiswaan, khususnya pelaksanaan program-program diluar kurikuler. Organisasi siswa diperlukan dalam usaha memberikan wadah bagi para siswa dalam menumbuhkan dan mengembangkan berbagai minat, bakat, dan kreativitas melalui programprogram kokurikuler, maupun diluar kurikuler serta dalam usaha menunjang keberhasilan program kurikuler.

Menurut wawancara penulis dengan 10 guru dan pegawai peran kepala sekolah sebagai pendidik di SMP PGRI 03 Kencong-Jember merupakan unsur yang penting dalam meningkatkan proses belajar mengajar di sekolah, oleh karena itu guru diharapkan menjadi pendidik kreatif, bermotivasi tinggi dan berakhlah mulia. Kesemuanya itu dapat dicapai apabila guru dalam melaksanakan tugas mendapat kepuasan dalam diri pekerjaanya. Apabila keperluannya dapat terpenuhi guru akan mempunyai nilai dan sikap yang positif dalam melaksanakan pekerjaannya bertujuan untuk mendapatkan pendidikan yang lebih baik.

Kepala sekolah dalam proses belajar mengajar di SMP PGRI 03 Kencong-Jember memakai metode tanya jawab, penugasan dan diskusi, dengan tanya jawab kepala sekolah mengharapkan metode yang diterapkan di sekolah dapat melatih keberanian siswa untuk mengajukan pendapat yang ada pada diri siswa selain itu dengan tanya jawab kepala sekolah juga mengharapkan siswa 
dapat bertukar pengetahuan dengan guru dan siswa - siswi yang lain dengan begitu akan mempererat hubungan antara siswa dan guru mata pelajaran.

Dengan penugasan kepala sekolah mengharapkan dapat melatih siswa - siswi untuk memiliki rasa tanggung jawab serta dapat mengerjakan tugas yang guru berikan kepada siswa siswi, dengan menumbuhkan rasa tanggung jawab kepala sekolah mengharapkan siswa - siswi akan memiliki rasa tanggung jawab tersebut sampai lulus, sampai perguruan tinggi atau dunia pekerjaan dan dalam kehidupan yang akan berlanjut dalam masyarakat.

\section{Kepala Sekolah Sebagai Administrator}

Kepala Sekolah sebagai administrator yaitu, kepala sekolah harus mampu menguasai tugas-tugasnya dan melaksanakan tugasnya dengan baik. Untuk itu kepala sekolah harus kreatif mampu memiliki ide-ide dan inisiatif yang menunjang perkembangan sekolah. Berbagai tugas yang harus dilakukan kepala sekolah antara lain membuat perencanaan yaitu Perencanaan yang perlu dilakukan oleh kepala sekolah, diantaranya adalah menyusun program tahunan sekolah, yang mencakup program pengajaran, kesiswaan, kepegawaian, keuangan, dan penyediaan fasilitasfasilitas yang diperlukan.

Perencanaan ini selanjutnya dituangkan dalam rencana tahunan sekolah yang dijabarkan dalam dua program semester. Kepala sekolah sebagai administrator sangat diperlukan karena kegiatan di sekolah tidak terlepas dari pengelolaan administrasi yang bersifat pencatatan dan pendokumentasian seluruh program sekolah. Kepala sekolah dituntut memahami dan mengelola kurikulum, administrasi peserta didik, administrasi sarana dan prasarana, dan administrasi kearsipan. Kegiatan tersebut perlu dilakukan secara efektif agar administrasi sekolah dapat tertata dan terlaksana dengan baik. Kemampuan kepala sekolah sebagai administrator harus diwujudkan dalam penyusunan kelengkapan data administrasi pembelajaran, bimbingan dan konseling, kegiatan praktikum, kegiatan di perpustakaan, data administrasi peserta didik, guru, pegawai TU, penjaga sekolah, teknisi dan pustakawan, kegiatan ekstrakurikuler, data administrasi hubungan sekolah dengan orang tua murid, data administrasi gedung dan ruang dan surat menyurat.

Kepala sekolah dalam perannya sebagai administrator dalam hal ini juga berkenaan dengan keuangan, bahwa untuk tercapainya peningkatan kompetensi guru tidak lepas dari faktor biaya. Seberapa besar sekolah dapat mengalokasikan anggaran peningkatan kompetensi guru tentunya akan mempengaruhi terhadap tingkat kompetensi para gurunya. Masalah keuangan adalah masalah yang peka. Oleh karena itu dalam mengelola bidang ini kepala sekolah harus hati-hati, jujur dan terbuka agar tidak timbul kecurigaan baik dari staf maupun dari masyarakat atau orang tua murid.

Dari hasil penelitian yang penulis lakukan dengan 10 guru dan pegawai di SMP PGRI 03 Kencong-Jember kepala sekolah dituntut dapat membuat perencanaan kegiatan yang akan di laksanakan di SMP PGRI 03 Kencong-Jember dan di sesuaikan dalam administrasi keuangan yang ada di sekolah ini artinya kepala sekolah dalam membuat perencanaan yang akan di adakan di 
sekolah harus dapat memprioritaskan apa yang lebih penting dan mendesak untuk di laksanakan seperti melengkapi apa yang kurang di sekolah seperti buku - buku di perpustakaan yang mmasih belum lengkap.

Tetapi dalam hal ini kepala sekolah belum dapat melaksanakan perannya sebagai administrasi dengan baik ini terbukti kepala sekolah belum dapat bersikap trasparan dalam membahas tentang administrasi keuangan tidak semua guru dan pegawai terlibat dalam pembahasan administrasi keuangan sehingga dapat menimbulkan kecemburuan sosial yang mungkin terjadi dalam lingkup sekolah. Dengan demikian kepala sekolah harus lebih trasparan dan dapat melengkapi kebutuhan yang kurang dengan menggunakan administrasi keuangan yang lebih bijak serta terbuka kepada semua guru dan pegawai yang ada di SMP PGRI 03 Kencong-Jember

\section{Kepala Sekolah Sebagai Motivator}

Peran kepala sekolah sebagai motivator adalah memberi dorongan kepada seluruh guru / pegawai agar aktif dan mampu menjalankan pekerjaan sesuai dengan metode dan prosedur yang telah ditetapkan, karena dengan motivasi yang diberikan oleh kepala sekolah maka guru dan pegawai akan merasa mendapatkan dorongan atau semangat. Dalam hal ini kepala sekolah harus memiliki strategi yang tepat dan mengetahui keadaan psikologi seluruh guru / pegawai agar kepala sekolah dapat mengetahui bagaimana cara memotivasi atau memberikan dorongan kepada guru / pegawai agar dapat melaksanakan tugas dan pekerjaannya dengan penuh rasa tanggung jawab serta dapat mencapai tujuan yang telah ditentukan bersama.

Dalam perannya sebagai motivator kepala sekolah harus paham bahwa motivasi merupakan suatu bagian yang sangat penting di sekolah, guru dan pegawai akan bekerja dengan sungguh - sungguh apabila memiliki motivasi yang tinggi. Apabila guru dan pegawai memiliki motivasi positif maka guru dan pegawai akan lebih memperlihatkan minat, mempunyai perhatian dan ingin ikut serta dalam suatu tugas dan pekerjaan. Dengan kata lain guru dan pegawai akan melaksanakan pekerjaannya dengan baik apabila ada faktor motivasi atau dorongan yang tinggi dari kepala sekolah.

Kepala sekolah harus mampu membangun motivasi kerja yang baik bagi seluruh guru, karyawan, dan berbagai pihak yang terlibat di sekolah. Kemampuan dalam membangun motivasi yang baik akan membangun produktivitas organisasi dan meningkatkan efisiensi kerja. Dengan motivasi yang tinggi, didukung dengan kemampuan guru dan keryawan yang memadai, akan memacu kenerja lembaga secara keseluruhan. Karenanya, kemampuan membangun motivasi menjadi salah satu kunci untuk meningkatkan performa dan produktivitas kerja.

Kepala sekolah selalu memberikan motivasi serta semangat kepada guru agar dapat menghadapi siswa - siswi yang memiliki tingkah laku yang berbeda - beda artinya kepala sekolah harus mampu memberikan motivasi kepada guru untuk selalu bersikap sabar dan tabah karena menghadapi siswa - siswi yang pastinya memiliki tingkah laku, standar pemikiran dalam menerima 
pelajaran yang berbeda - beda, oleh karena itu kepala sekolah harus lebih memperhatikan guru dalam memberikan motivasi agar dapat mencapai tujuan sekolah yang telah ditentukan bersama sama.

\section{Kendala yang Dihadapi Kepala Sekolah dalam Meningkatkan Efektivitas Kerja Guru dan Pegawai}

Kepala sekolah SMP PGRI 03 Kencong-Jember dalam melaksanakan perannya mendapatkan hambatan yaitu kurangnya disiplin guru dalam hal jadwal pelajaran yang telah ditentukan sekolah, karena masih ada guru yang menjemput anaknya sekolah dan meninggalkan pelajaran yang telak dilaksanakan di sekolah, selain itu ada juga guru yang menbawa anaknya ke sekolah sehingga dapat mengganggu waktu mengajar guru tersebut. Dalam mengatasi hal ini kepala sekolah telah menegur dengan lisan tetapi masih ada juga guru yang mengulanginya dengan alasan anaknya sendirian di rumah.

Kepala sekolah pun mendapatkan hambatan dalam hal saran dan prasarana yang masih kurang di SMP PGRI 03 Kencong-Jember karena melihat keberhasilan program pendidikan melalui proses belajar mengajar sangat dipengaruhi oleh banyak faktor, salah satu di antaranya adalah tersedianya sarana dan prasarana pendidikan yang memadai disertai pemanfaatan dan pengelolaan secara optimal. Sarana dan prasarana pendidikan merupakan salah satu sumber daya yang penting dan utama dalam menunjang proses pembelajaran di sekolah, untuk itu perlu dilakukan peningkatan dalam pendayagunaan dan pengelolaannya.

Kurangnya sarana dan prasarana yang di miliki SMP PGRI 03 Kencong-Jember antara lain listrik yang belum memenuhi kebutuhan yang diperlukan sekolah sehingga sekolah membutuhkan mesin generator (mesin lampu) untuk memenuhi kebutuhan sekolah, kurangnya buku pelajaran / buku bacaan yang masih kurang di perpustakaan dan belum adanya Unit Kesehatan Sekolah (UKS), ini menjadi tugas kepala sekolah yang tidak kalah penting untuk memenuhinya.

\section{SIMPULAN}

1. Peran Kepemimpinan Kepala Sekolah di SMP PGRI 03 Kencong-Jember Kepala sekolah sebagai pemimpin yaitu kepala sekolah melakukan tanggung jawab melakukan perbaikan dan pengajaran. Keadaan tersebut dilandasi oleh anggapan bahwa tujuan utama penyelenggaraan pendidikan melalui sekolah adalah terciptanya lingkungan yang kondusif, sehingga proses belajar mengajar dapat tercapai secara efektif.

2. Kepala sekolah sebagai menajer dalam mempengaruhi guru untuk mewujudkan tujuan yang diinginkan. Sebagai manajer kepala sekolah harus mau dan mampu mendayagunakan seluruh sumber daya sekolah dalam maeningkatkan visi, misi dan memcapai tujuan sekolah.

3. Kepala sekolah berperan sebagai pendidik mencakup dua hal pokok yaitu sasaran atau kepada siapa perilaku sebagai pendidik itu diarahkan dan bagaimana peran sebagai pendidik itu dilaksanakan 
4. Kepala sekolah berperan sebagai administrator sangat diperlukan karena kegiatan di sekolah tidak terlepas dari pengelolaan administrasi yang bersifat pencatatan dan pendokumentasian seluruh program sekolah. Kepala sekolah dalam perannya sebagai administrator dalam hal ini juga berkenaan dengan keuangan, bahwa untuk tercapainya peningkatan kompetensi guru tidak terlepas dari faktor biaya.

5. Kepala sekolah berperan sebagai motivator dengan memberikan motivasi kepada guru dan pegawai, serta mengatur lingkungan fisik dan suasana kerja. Apabila guru dan pegawai memiliki motivasi yang positif maka guru dan pegawai akan lebih memperhatikan miniat, mempunyai perhatian dan ikut serta dalam suatu tugas dan pekerjaan. Dengan kata lain guru dan pegawai akan melaksanakan pekerjaannya dengan baik apabila ada factor motivasi dorongan yang tinggi dari kepala sekolah.

6. Kendala yang dihadapi oleh Kepala Sekolah di SMP PGRI 03 Kencong-Jember yaitu kepala sekolah merasa guru dan pegawai yang kurang disiplin dalam melaksanakan tugas dan pekerjaannya, dan kendala dalam sarana dan prasarana.

\section{SARAN}

1. Kepala sekolah agar dapat menciptakan lingkungan sekolah yang nyaman, suasana kerja yang aman dan suasana yang menyenangkan supaya guru dan pegawai dapat melaksanakan tugas dan pekerjaannya dengan penuh rasa tangung jawab.

2. Kepala sekolah dalam perannya sebagai administrator agar dapat lebih trasparan dalam memberikan informasi administrasi terutama keuangan dan dapat berkomunikasi kepada guru dan pegawai di sekolah.

3. Bagi guru agar dalam proses belajar mengajar hendaknya lebih bervariasi dalam memberikan materi pelajaran agar lebih mudah di mengerti siswa - siswi.

4. Kepala sekolah agar dapat meningkatkan sarana dan prasarana yang kurang dalam menunjang proses belajar mengajar. Contoh melengkapi buku - buku yang kurang di perpustakaan, melengkapi komputer yang sangat masih kurang di sekolah, membangun UKS (unit kesehatan sekolah).

5. Kepada masyarakat atau orang tua siswa-siswi agar dapat berpartisipasi dalam membantu kepala sekolah dan guru untuk memberikan saran dan kritik untuk dapat meningkatkan kualitas sekolah.

\section{DAFTAR PUSTAKA}

Arikunto, Suharsimi. 2006. Prosedur Penelitian Suatu Pendekatan Praktik (Edisi Revisi VI). Jakarta: PT Rineka Cipta.

Hasibuan, Malayu. 2000. Manajemen Sumber Daya Manusia. Jakarta : Bumi Aksara.

Joewono, Heri. 2002. Pokok-Pokok Kepemimpinan Abad 21. Jakarta: Balai Pustaka. 
Kartono, Kartini. 2008. Pemimpin dan Kepemimpinan. Jakarta: PT Raja Grafindo Persada.

Mangkunegara, Prabu Anwar. 2004 Evaluasi Kinerja Sumber Daya Manusia. Bandung: PT. Refika Aditama

Miles, B. Matthew dan A. Michael Huberman. 2007. Analisis Data Kualitatif, Buku Sumber Tentang Metode-Metode Baru. Jakarta: Penerbit Universitas Indonesia.

Moleong, Lexy. 2000. Metodologi Penelitian Kualitatif(direvisi). Bandung: PT Rosda Karya. 